\title{
Characidium heirmostigmata, a new characidiin fish (Characiformes: Crenuchidae) from the upper rio Paraná basin, Brazil
}

\author{
Weferson J. da Graça and Carla S. Pavanelli
}

Characidium heirmostigmata new species is described from the rio Ivaí drainage, upper rio Paraná basin, Paraná State, Brazil. The new species is diagnosed among its congeners by the possession of eight to 11 incomplete oblique dark bars on the body sides, extending upwards and downwards from the lateral line, independently of the eight or nine dorsal transverse bars usually present in species of Characidium. The new species is similar to Characidium serrano from the upper rio Uruguay basin, but differs by meristic and morphometric traits.

Characidium heirmostigmata espécie nova é descrita da drenagem do rio Ivaí, bacia do alto rio Paraná, Estado do Paraná, Brasil. A nova espécie é diagnosticada de suas congêneres por apresentar oito a 11 barras escuras, oblíquas e incompletas nas laterais do corpo, para cima e para baixo da linha lateral, independentemente das oito ou nove barras transversais que geralmente estão presentes nas espécies de Characidium. A nova espécie é similar a Characidium serrano, da bacia do alto rio Uruguai, porém difere em caracteres merísticos e morfométricos.

Key words: Characidiinae, rio Ivaí basin, Neotropical, Systematics, South American darters.

\section{Introduction}

Characidiinae is a monophyletic group of small Neotropical freshwater fishes (Buckup, 1993a). Characidium Reinhardt, 1867 is the most speciose diverse genus of this subfamily, with about 50 nominal species (Buckup, 2003; Buckup, 2007). They are small sized fishes, which do not surpass $100 \mathrm{~mm}$ of SL, widespread in Neotropical rivers (Buckup, 1993a). Buckup (1993b) provisionally diagnosed Characidium (in a phylogenetic sense) by the presence of a black spot near the base of the middle caudal-fin rays. New species of Characidium have been recently described by Buckup \& Reis (1997), Buckup \& Hahn (2000), Zarske \& Géry (2001), Melo \& Buckup (2002) and Taphorn et al. (2006). This paper describes a new species collected by the staff of Nupélia (Núcleo de Pesquisas em Limnologia, Ictiologia e Aqüicultura, Universidade Estadual de Maringá), in three affluents of the rio Ivaí, upper rio Paraná basin, State of Paraná, Brazil.

\section{Material and Methods}

Measurements and counts follow Buckup (1993c). Measurements were taken with digital calipers to the nearest 0.01 $\mathrm{mm}$ on the left side of the specimens and expressed as percents of Standard Length (SL) and Head Length (HL). Counts are described in the text, with the number of specimens for each count between parentheses, and the holotype data marked with an asterisk. Three paratypes of Characidium heirmostigmata were cleared and stained according to Taylor \& Van Dyke (1985) procedures, in order to count vertebrae, ecto and mesopterygoid teeth, branchiostegal rays and ural bones, and for other osteologic observations. Cleared and stained specimens are represented by c\&s. Institutional abbreviations follow standard ASIH codons listed at http://199.227.217.251/files/ codons.pdf, with the addition of NUP (Coleção Ictiológica do Nupélia, Universidade Estadual de Maringá). Morphological data of C. borellii, C. etzeli, C. oiticicai, and C. pterostictum are based on literature accounts (Géry et al. 2001; Zarske \& Géry, 2001; Melo, 2001; Buckup \& Reis, 1997, respectively).

\section{Characidium heirmostigmata, new species}

Figs. 1 and 2

Holotype. MZUSP 97738, 35.0 mm SL, Brazil, Paraná, Município de Prudentópolis, upper rio Paraná basin, rio Barra Grande, tributary to left margin of rio Ivaí, approx. $24^{\circ} 40^{\prime} \mathrm{S} 51^{\circ} 15^{\prime} \mathrm{W}, 3 \mathrm{Apr} 2007$, C. H. Zawadzki \& W. J. Graça.

Universidade Estadual de Maringá, Núcleo de Pesquisas em Limnologia, Ictiologia e Aqüicultura (Nupélia), Programa de Pós Graduação em Ecologia de Ambientes Aquáticos Continentais, Av. Colombo 5790, 87020-900 Maringá, PR, Brazil. wefersonwjg@yahoo.com.br, carlasp@nupelia.uem.br 
Paratypes. Brazil, Paraná, upper rio Paraná basin: MZUSP 97739 , 1, $28.1 \mathrm{~mm} \mathrm{SL}$, collected with the holotype. MCP 41935, 3, 38.8$52.7 \mathrm{~mm}$ SL; MZUSP 97740, 5, 38.9-41.9 mm SL, NUP 1411, 4, 42.5-46.5 mm SL; NUP 5333, 2 c\&s, 38.9-44.6 mm SL: Município de Cândido de Abreu, rio Nestor, tributary to right margin of rio Ivaí, approx. 2428'S 5054'W, 22 Nov 1994, Nupélia. MNRJ 31594, 8, 44.2-54.0 mm SL; NUP 1381, 8, 40.2-45.6 mm SL; NUP 1393, 3, 45.3-50.0 mm SL; NUP 5334, 1 c\&s, 37.5 mm SL: Município de Jussara, rio Abelha, tributary to left margin of rio Ivaí, approx. $23^{\circ} 36^{\prime}$ 'S 52²8'W, 17 Nov 1994, Nupélia.

Diagnosis. Characidium heirmostigmata can be distinguished from all other congeners, except $C$. serrano (upper rio Uruguai basin), by the presence of eight to 11 incomplete oblique bars on body sides, extending upwards and downwards from the lateral line and independent of the eight or nine dorsal transverse bars which usually are present in Characidium species. Characidium heirmostigmata differs from $C$. serrano by wider body width (12.2 to $15.7 \%)$ and shorter number of perforated scales on lateral line (32-35) vs 8.7 to $11.1 \%$ in SL, and $37-39$ scales in C. serrano.

Description. Morphometric data summarized in Table 1. Body fusiform, moderately compressed. Dorsal profile convex between anterior tip of snout and dorsal-fin origin, except for small concavity due to inflexion of supraocciptal process, almost straight between bases of dorsal and caudal fins. Ventral profile convex, moderately arched between lower lip and posterior end of pelvic-fin base, straight between pelvic-fin base and anal-fin origin, and slightly concave between pel-

vic-fin origin and caudal fin base. Greatest body depth at dorsal-fin origin.

Snout blunt and rounded, its tip at about same level as ventral margin of orbit. Mouth small and subterminal. Maxillary bone moderately elongated, reaching anterior margin of orbital. Orbit circular, slightly larger than snout length. Cheek smaller than orbit, its depth about one-third of orbit diameter.

Table 1. Morphometric data of Characidium heirmostigmata $(\mathrm{n}=33)$, range including data of the holotype. SD: standard deviation.

\begin{tabular}{lllll}
\hline Characters & Holotype & Range & Mean & SD \\
\hline Total length (mm) & 43.4 & $35.9-66.5$ & 53.5 & \\
Standard length (mm) & 35.0 & $28.1-54.0$ & 44.1 & \\
Percentages of standard length & & & & \\
Body depth at dorsal-fin origin & 20.0 & $20.0-26.6$ & 24.6 & 1.3 \\
Body depth at anal-fin origin & 12.9 & $11.0-14.5$ & 13.3 & 0.9 \\
Caudal-peduncle depth & 10.0 & $9.6-12.3$ & 11.3 & 0.7 \\
Head length & 22.9 & $22.4-24.6$ & 23.5 & 0.6 \\
Caudal-peduncle length & 19.4 & $15.6-21.4$ & 17.9 & 1.5 \\
Preanal distance & 74.6 & $71.9-77.3$ & 74.8 & 1.4 \\
Predorsal distance & 43.5 & $43.5-48.1$ & 46.0 & 1.5 \\
Prepectoral distance & 22.6 & $20.5-26.0$ & 23.4 & 1.0 \\
Prepelvic distance & 51.4 & $46.1-52.8$ & 49.4 & 1.5 \\
Anal to apex distance & 92.3 & $86.0-94.3$ & 91.3 & 1.2 \\
Body width & 12.3 & $12.2-15.7$ & 13.4 & 0.9 \\
Percentages of head length & & & & \\
Snout length & 26.2 & $20.3-27.8$ & 24.3 & 1.5 \\
Orbital diameter & 27.5 & $27.3-31.9$ & 29.3 & 1.1 \\
Cheek depth & 13.1 & $11.9-15.4$ & 13.4 & 0.8 \\
Anterior naris to orbit & 12.5 & $8.6-12.5$ & 10.7 & 1.0 \\
Posterior naris to orbit & 5.2 & $3.8-5.7$ & 4.7 & 0.5 \\
Snout to maxillary tip & 25.0 & $20.0-25.6$ & 22.8 & 1.5 \\
Interorbital distance & 23.7 & $21.0-25.5$ & 23.2 & 1.3 \\
\hline
\end{tabular}

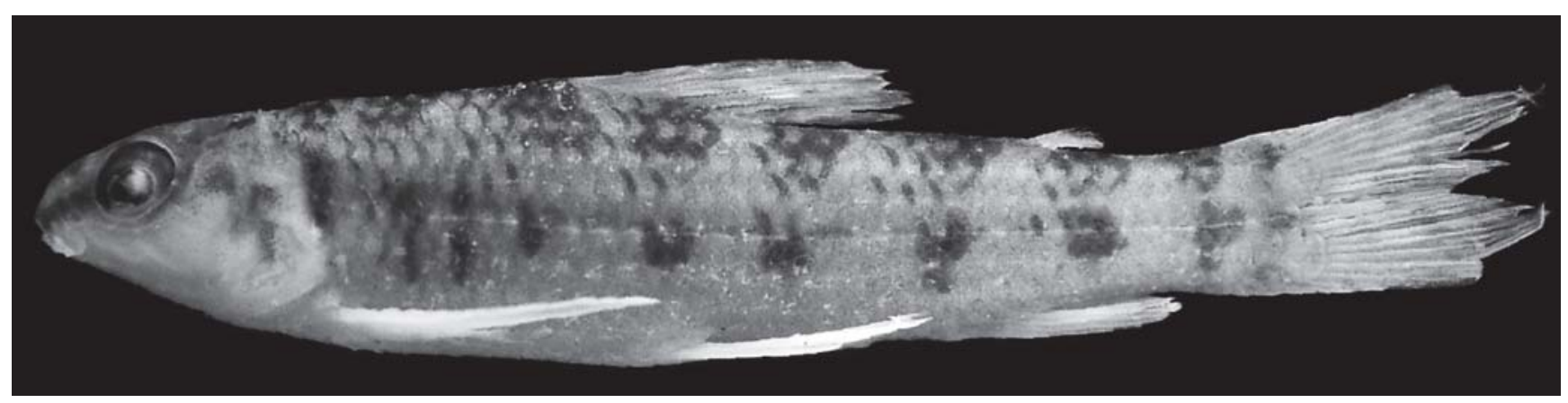

Fig. 1. Characidium heirmostigmata, holotype, MZUSP 97738, $35.0 \mathrm{~mm}$ SL. Picture horizontally flipped.

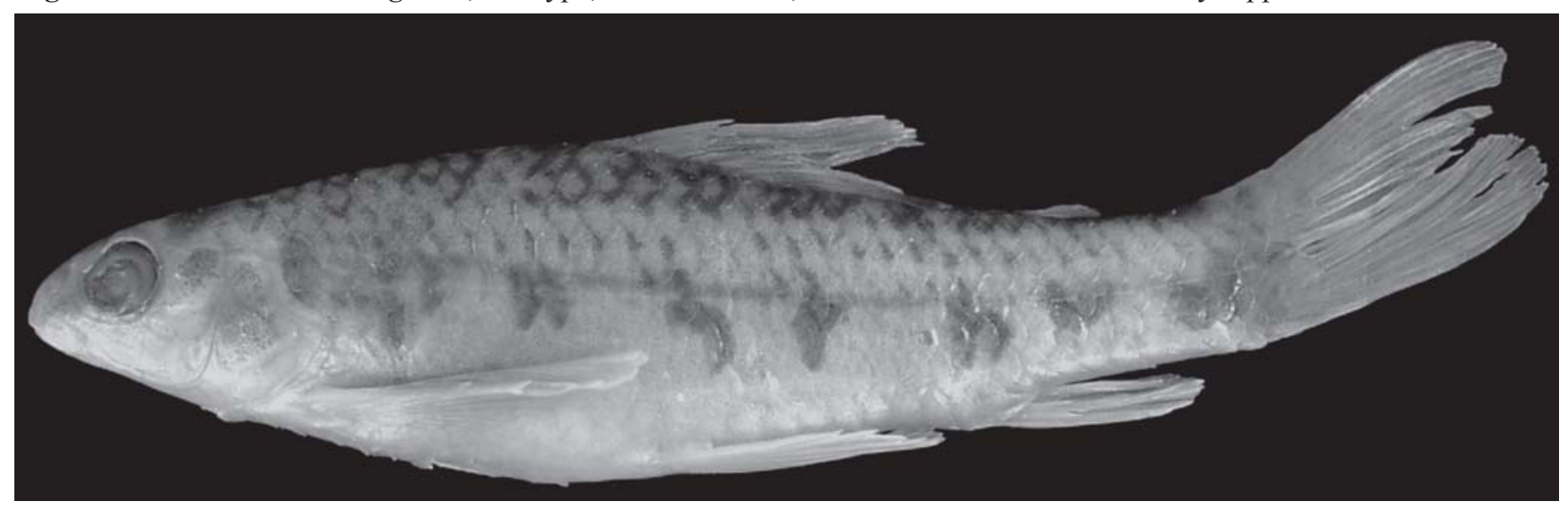

Fig. 2. Characidium heirmostigmata, paratype, NUP 1393, 40.8 mm SL. 
Nares separated; posterior naris considerably closer to eye than to anterior naris; margin of anterior naris raised, forming circular rim; dermal flaps sometimes present in posterior naris. Supraorbital present, somewhat triangular in dorsal view, medial edge abutting frontal, anterior end narrow and directed away from frontal. Parietal branch of supraorbital canal absent. Parietal fontanel anteriorly limited by frontals. Branchiostegal rays $4(3)$; three attached to anterior ceratohyal and one to posterior ceratohyal. Orbitosphenoid slightly rectangular in lateral view, connected anteriorly to rhinosphenoid, posteriorly with pterosphenoid, with posterior-ventral free margin concave. Pterosphenoid foramen for ophthalmic nerve relatively small, formed by tunnel crossing pterosphenoid diagonally, bordered ventrally by bony crest, preventing direct lateral view of brain cavity through foramen. Gill-rakers 7(33*) on cerato and $4\left(33^{*}\right)$ on epibranchial limb of first branchial arch.

Outer dentary teeth $8\left(33^{*}\right)$, gradually decreasing in size, with three triangular cusps, occasionally with minute lateral cusp on medialmost teeth. Inner dentary teeth absent. Premaxillary teeth 6(4), 7(22*) or 8(7), all conic, posteriorly curved. Ectopterygoid teeth conic in single row 5(1), 6(1) or 8(1). Mesopterygoid teeth absent (3).

Scales cycloid; about 10-12 radii on posterior field of large scales. Small axillary scale present on pelvic-fin insertion, its tip extending about two or three scales posteriorly $\left(33^{*}\right)$. Lateral line complete 32(6), 33(6*), 34(19) or 35(2) perforated scales. Scale rows above lateral line 4(19) or 5(14*); and below $4(13)$ or $5\left(20^{*}\right)$. Scales in predorsal series $12\left(33^{*}\right)$. Scales around caudal peduncle $12\left(33^{*}\right)$. Isthmus completely scaled.

Dorsal-fin rays iii, 10(24*) or iii,11(9); pectoral-fin rays iii,10(26*) or iii,11(7); pelvic-fin rays i,8(20*) or i,9(13); analfin rays ii,8(14*) or ii,9(19); caudal-fin rays i,9,8,i(33*). All fins with posterior margin rounded, except bifurcate caudal fin. Adipose fin present.

Total number of vertebrae 34(3). Supraneurals between neural spine of fourth centrum and first dorsal-fin pterygiophore 4(3). Epurals 3(3). Uroneural present (3).

Color in alcohol. Background color of head and body pale yellow. Chromatophores distributed over entire surface of head, including cheek and gular area, more densely on dorsolateral region; diffuse, oblique, dark stripe extending from tip of snout to anterior margin of orbit, continuing longitudinally from posterior margin of orbit to preopercle. Dark humeral spot conspicuous and vertically elongate. Chromatophores near edge of exposed area of scales above lateral line forming reticulate pattern. Thin dark brown, longitudinal midlateral stripe accompanying lateral line, sometimes inconspicuous. Dark middorsal blotches $8\left(12^{*}\right)$, 9(21). Vertical bars on body sides not corresponding in number or position to middorsal blotches; bars irregular, vertical or anteriorly tilted $8\left(10^{*}\right), 10(12)$ or $11(11)$ extending down and backward from lateral line scales. Small, black spot near base of middle caudal-fin rays. Pectoral, pelvic, and anal fins hyaline. Dorsal fin with insconspicuous dark, transverse bands. Caudal fin with irregular vertical bands.
Sexual dimorphism. External sexual differences between males and females of Characidium heirmostigmata, such as coloration pattern or hooks on fins, were not found, even with the examination of breeding males and two living specimens.

Distribution. Known only from rio Abelha, rio Barra Grande, and rio Nestor, tributaries to rio Ivaí, upper rio Paraná basin, Paraná State, Brazil (Fig. 3).

Etymology. From the Greek heirmos (series) plus stigmata (plural of stigma $=$ marks), referring to the series of black marks present on the body sides. A noun in apposition.

Common name. Characidium heirmostigmata is popularly known in the sampled region as "canivete" or "mocinha".

\section{Discussion}

Buckup (2003) listed from the rio Paraná basin Characidium borellii (Boulenger, 1895) (Andean tributaries to rio Paraná basin in northwestern Argentina), C. etzeli Zarske \& Géry, 2001 (rio Paraná basin in Paraguay), C. fasciatum Reinhardt, 1867 (rio Paranaíba, rio Grande, rio Tietê and rio São Francisco basins), C. gomesi Travassos, 1956 (rio Grande, rio Tietê and rio Paranapanema basins), C. laterale (Boulenger, 1895) (rio Paraná basin in Paraguay), C. oiticicai Travassos, 1967, (rio Tietê and rio Ribeira do Iguape basins), and C. schubarti Travassos, 1955 (rio Paranapanema basin). Other species from adjoining basins listed by Buckup (2003) are Characidium lanei Travassos, 1967 (coastal basins between southeastern Brazil in Paraná State and rio Ribeira do Iguape basin), and C.pterostictum Gomes, 1947 (rio Ribeira do Iguape and rio Uruguay basins).

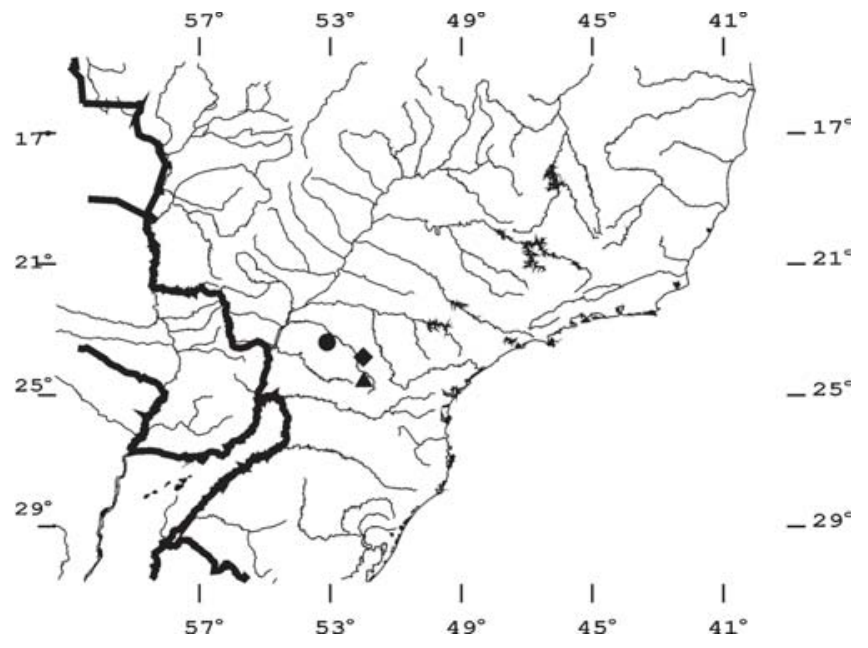

Fig. 3. Partial map of Brazil and adjoining countries, showing the distribution of the new species. Triangle refers to the type-locality of Characidium heirmostigmata (rio Barra Grande), losangle demonstrates rio Nestor and dot indicates rio Abelha, all affluents of the rio Ivaí, upper rio Paraná basin. Symbols represent more than one lot of paratypes. 
Characidium heirmostigmata can be distinguished from all species mentioned above, mainly by color pattern, and additionally for the completely scaled isthmus, (vs naked isthmus in C.fasciatum, C. gomesi, C. lanei, C. oiticicai and $C$. shubarti); complete lateral line (vs incomplete in $C$. laterale); 12 scales around caudal peduncle (vs 14 in C. borellii, and $C$. pterostictum).

Irregular bars on body are also exhibited by members of the C. lauroi species-group (sensu Melo, 2001), formed by: $C$. japuhybense Travassos, 1949 (coastal streams of southeastern Brazil from Ilha Grande Bay to rio Ribeira de Iguape basin), C. lauroi Travassos, 1949 (rio Paraíba do Sul basin), C. oiticicai, C. schubarti, and other two undescribed species. But members of this group possess small rounded dots along the side of the body ( $v s$ absent in $C$. heirmostigmata).

Characidium is currently considered a monophyletic group based on one synapomorphy: a black spot near the base of middle caudal-fin rays (Buckup, 1993b). As Melo \& Buckup (2002) stated, Characidium species have not been yet adequately classified into subgroups, but probably, Characidium heirmostigmata and C. serrano form a putative monophyletic group, uniquely diagnosed by the body side bars color pattern described above.

For approximately forty years no Characidium species have been described from the upper rio Paraná basin. The discovery of the new species in the rio Ivaí drainage suggests that new efforts must be made for further collecting in the upper rio Paraná basin, mainly in its tributaries of the Paraná State. This fact is corroborated by Pavanelli (2006) in her recent description of Apareiodon vladii from the rio Piquiri basin.

Comparative material: All from Brazil, Goiás. Characidium gomesi. NUP 1092, 7, 40.0-52.1 mm SL, Caldas Novas, rio Corumbá; NUP 3815, 1, 41.2 mm SL, Terezópolis, córrego Maria Paula; NUP 3816, 2, 40.0-57.5 mm SL, Anápolis, córrego Cunha. Characidium sp. aff. C. zebra. NUP 1196, 100, 40.0-68.9 mm SL, Caldas Novas, rio Corumbá; NUP 1206, 54, 42.0-69.0 mm SL, Caldas Novas, rio Gameleira; NUP 2302, 3, 52.0-65.0 mm SL, Mineiros, rio Formoso (Parque Nacional das Emas). Paraná. NUP 1384, 4, 53.0-75.8 mm SL, Jussara, rio Abelha. Santa Catarina. C. serrano. MCP 12488, holotype, $50.0 \mathrm{~mm}$ SL, Concórdia, rio Jacutinga; MCP 12038, paratype, $47.5 \mathrm{~mm} \mathrm{SL}$, Campos Novos, rio Canoas. São Paulo. $C$. lanei. MZUSP 87604, 3 of 17, 37.7-40.1 mm SL, Bertioga, unnamed stream tributary to rio Vermelho. C. lauroi. MZUSP 71848, 10, 15.2-45.4 mm SL, Guapiara, córrego de Francisca Gomes (Parque Estadual de Intervales).

\section{Acknowledgements}

Thanks are due to Mário de Pinna and Osvaldo Oyakawa (MZUSP), Zilda Lucena and Roberto Reis (MCP), and to Oscar Shibatta (MZUEL) for loaning and allowing examination of material; to Cláudio Zawadzki (UEM/Nupélia), Álvaro Maier, and Hilker Voegel (UNICENTRO) for helping in sampling at rio Barra Grande. Paulo Lucinda (UFT) critically reviewed and improved the manuscript. Harumi Suzuki and Marli Campos (UEM/Nupélia) gently identified the fish sex. Nupélia offered logistic support. WJG was supported by grants from CAPES (Coordenação de Aperfeiçoamento de Pessoal de Nível Superior) and CSP from CNPq (Conselho Nacional de Desenvolvimento Científico e Tecnológico, proc. 311975/2006-2).

\section{Literature Cited}

Buckup, P. A. 1993a. The monophyly of the Characidiinae, a Neotropical group of characiform fishes (Teleostei, Ostariophysi). Zoological Journal of the Linnean Society, 108: 225-245.

Buckup, P. A. 1993b. Phylogenetic interrelationships and reductive evolution in Neotropical characidiin fishes (Characiformes, Ostariophysi). Cladistics, 9: 305-341.

Buckup, P. A. 1993c. Review of the characidiin fishes (Teleostei: Characiformes), with descriptions of four new genera and ten new species. Ichthyological Exploration of Freshwaters, 4(2): 97-154.

Buckup, P. A. 2003. Family Crenuchidae (South American darters). Pp. 87-95. In: Reis, R. E., S. O. Kullander \& C. J. Ferraris, Jr., (Eds.). Check List of the Freshwater Fishes of South and Central America. Porto Alegre, Edipucrs, 729p.

Buckup, P. A. 2007. Família Crenuchidae. Pp. 28-30. In: Buckup, P. A., N. A. Menezes \& M. S. Ghazzi (Eds.). Catálogo das espécies de peixes de água doce do Brasil. Rio de Janeiro, Museu Nacional, 195p.

Buckup, P. A. \& L. Hahn. 2000. Characidium vestigipinne: a new species of Characidiinae (Teleostei, Characiformes) from Southern Brazil. Copeia, 2000(1): 150-155.

Buckup, P. A. \& R. E. Reis. 1997. Characidiin genus Characidium (Teleostei, Characiformes) in Southern Brazil, with description of three new species. Copeia, 1997(3): 531-548.

Géry, J., A. Zarske \& H. J. Paepke. 2001. Supplementary descriptions of two overlooked fish taxa, Leporinus macrolepidotus Peters, 1868, and Nanognathus borellii Boulenger, 1895, actually members of the genus Characidium Reinhardt, 1866 (Teleostei: Characiformes: Characidiidae). Zoologische Abhandlungen Staatliches Museum für Tierkunde Dresden, 51(3): 23-31.

Melo, M. R. S. 2001. Sistemática, filogenia e biogeografia do grupo Characidium lauroi Travassos, 1949 (Characiformes, Crenuchidae). Unpublished M.Sc. Thesis, Universidade Federal do Rio de Janeiro, Rio de Janeiro. 95p.

Melo, M. R. S. \& P. A. Buckup. 2002. Characidium stigmosum (Characiformes: Crenuchidae): a new species of Characidiin fish from central Brazil. Copeia, 2002(4): 988-993.

Pavanelli, C. S. 2006. New species of Apareiodon (Teleostei: Characiformes: Parodontidae) from the rio Piquiri, upper rio Paraná basin, Brazil. Copeia, 2006(1): 89-95.

Taphorn, D. C. B., C. G. Montaña \& P. A. Buckup. 2006. Characidium longum (Characiformes: Crenuchidae), a new fish from Venezuela. Zootaxa, 1247: 1-12.

Taylor, W. R. \& G. C. Van Dyke. 1985. Revised procedures for staining and clearing small fishes and others vertebrates for bone and cartilage study. Cybium, 9: 107-119.

Zarske, A. \& J. Géry. 2001. Beschreibung von drei neuen Arten der Gattung Characidium Reinhardt, 1866 aus Bolivien und Paraguay (Teleostei: Characiformes: Characidiidae). Zoologische Abhandlungen Staatliches Museum für Tierkunde Dresden, 51(16): 229-246.

Accepted February 2008 Published 31 March 2008 